\title{
Accessibility patterns: Czech Republic Case Study ${ }^{1}$
}

\author{
Miroslav Marada, Viktor Květoň, Tomáš Mattern, Přemysl Štych, Tomáš Hudeček \\ Department of Social Geography and Regional Development, \\ Faculty of Science, Charles University in Prague \\ Albertov 6, 12843 Praha 2, Czech Republic \\ miroslav.marada@natur.cuni.cz,viktor.kveton@seznam.cz,tomas.mattern@natur.cuni.cz, \\ stych@natur.cuni.cz,hudecek@dr.com
}

\begin{abstract}
Czechia has a relatively high density of the road network, although the basic network of motorways has not been completed and does not match the actual needs. Some regional centres still do not have good connection to the network of motorways or higher-quality railway network. This situation affects the key results of the analysis performed:

1. The results for main regional centres' accessibility display significant geographic differentiation. On the one hand, they highlight the hinterland, while on the other hand the results show the most distant and peripheral areas located primarily at the borders with Poland and Bavaria. There are also the so-called inner peripheries in the Czech Republic, which can be found around the borders of the NUTS 3 regions.

2. The results for job accessibility by car are strongly affected by radial expressways around the main agglomerations. Expressing accessibility as a cumulated opportunity provides a new view of some peripheral areas when some municipalities located in-between several regional capitals can benefit from the offer of job opportunities in all surrounding centres.

3. Contrary to time and cumulated accessibility, the potential accessibility results show the main concentration areas and their locations in the transport networks in the Czech Republic. There is relative separation of the two historically independent settlement areas of Czechia (Moravia vs. Bohemia).
\end{abstract}

Keywords: accessibility, transport infrastructure, accessibility pattern, TEN-T, GIS, Czech Republic.

\section{Case study introduction}

Czechia is a landlocked country situated in Central Europe. Its area comprises the historical territories of Bohemia, Moravia and a part of Silesia. It borders Poland $(762 \mathrm{~km})$, Germany $(810 \mathrm{~km})$, Austria $(466 \mathrm{~km})$ and Slovakia $(252 \mathrm{~km})$. The capital city is Prague. Its surface area is $78,864 \mathrm{~km}^{2}$ ( $21^{\text {st }}$ in Europe) with a population of 10.5 million (12 $2^{\text {th }}$ in Europe). The average population density is

1 This paper has been developed under the applied research project TRansport ACCessibility at regional/local scale and patterns in Europe led by Spiekermann \& Wegener Urban and Regional Research (S\&W) Germany. It has been financed by the ESPON 2013 Programme and its financial support is gratefully acknowledged. Texts, maps and conclusions stemming from research projects under the ESPON programme presented in this paper do not necessarily reflect the opinions of the ESPON Monitoring Committee. (C) ESPON, 2013. 
approximately 133 inhabitants $/ \mathrm{km}^{2}$. Czechia is located between two mountain systems. The western and central part of the country is formed by Czech Highlands; the eastern part is formed by the Carpathian mountain range.

\section{Spatial structure}

Czechia can be divided into two levels of territorial self-governing units: the lower one (municipalities) and the higher one (regions or provinces; "kraj" in Czech). In 1997, a constitutional act established 14 higher territorial self-governing units (regions), which did not correspond to the regional demarcations valid between 1960 and 1989. However, this act did not regulate the organisation, the structure or competences of bodies at the regional level. Therefore, in the beginning the regional system functioned only formally (de jure). At the regional level, state administration and self-government started to work as late as 2000 (de facto). It means that since then Czech Republic has a new administrative structure of 14 NUTS 3 regions (Strategie rozvoje... 2006).

Municipalities administer their territories within the framework of autonomous competence. Within their self-competence, all municipalities (either villages, towns or cities) have equal rights and obligations. Besides, they execute delegated competences on behalf of the state. Execution of delegated competences depends on the size of the municipality and the territory it administers. Municipalities are divided into three groups according to the scope of competences delegated:

- Municipalities with the basic range of competence - of which there were 6,249 self-administrative municipalities as at 1 January 2010;

- Municipalities with authorised municipal offices - 388 municipalities whose municipal offices exercise transferred state competence, especially in the domain of offences, construction administration and agricultural land resources;

- Municipalities with extended powers - 205 municipalities, which exercise the largest range of the transferred state competence in their territory, especially in the domain of issuing passports, driving and trading licences, waste management, transport and road management, etc.

Czech NUTS 2 regions are always made up of one to three NUTS 3 regions called "kraj". NUTS 2 regions are only statistical units without self-government and responsibility. Coordination of NUTS 2 development is performed by so-called Regional Councils. On the other hand, NUTS 3 regions ("kraje") play a key role in regional and local development governance (National Strategic Reference Framework ...).

Czechia is characterised by a fragmented structure of settlements, with a historically high number of municipalities (6,249 in 2010). As mentioned above, there is a large number of municipalities of which only a minor part can be regarded as towns by international standards. Nonetheless urban areas play an important role in the development of the regions. From the point of view of functionality, the following urbanised areas (mostly regional capitals) can be identified: Prague agglomeration (population of 1.7 million), East-Bohemian agglomeration (Hradec Králové and Pardubice cities, population of 370,000), North-Bohemian conurbation $(650,000$; settlement belt Chomutov - Most - Teplice - Ústí nad Labem), Liberec agglomeration (200,000), Plzeň $(330,000)$, České Budějovice $(150,000)$, Karlovy Vary (200,000), Ostrava agglomeration $(890,000)$, Brno agglomeration $(590,000)$, Central-Moravian conurbation (Olomouc, 370,000) and Zlín (240,000). In general, the northern part of Czechia is more densely populated, and there is a higher rate of urbanisation; the area south of the line Karlovy Vary - Plzeň - Prague - Pardubice - Olomouc - Brno is rather rural, historically less industrialised. 
With regard to the potential for further development, Czech spatial development policy defines twelve main development areas. Far more frequent requests are made for zoning changes in the following areas because they are centres of international or nationwide businesses: Prague, Ostrava, Brno, Hradec Králové - Pardubice, Plzeň, Ústínad Labem, Liberec, Olomouc, Zlín, České Budějovice, Jihlava and Karlovy Vary. These development areas are linked by eleven development axes.

\section{Socio-economic situation}

Regional development and differences in Czechia are strongly influenced by the unique position of Prague in the Czech economy. The capital city of Prague (NUTS 2 region) is currently one of the most dynamic and most successful regions of Central Europe. Prague generates a quarter of the Czech GDP and its value is twice the Czech average and 155\% of the EU NUTS 2 average (2010). Prague is the key administrative centre in Czechia and has a modern services economy, specialising in financial services and activities related to tourism. As the largest city by far in Czechia (1.2 million), it is also the seat of the main national companies and the principal bodies concerned with scientific research and education. Prague has become a favoured destination for foreign banking during the transformation period in Czechia and has been holding this position to the present time. Prague belongs to the ten wealthiest regions in the whole European Union. At the same time, it is the wealthiest region in new EU Member States. On the other hand, Prague also faces a number of serious problems typical of large metropolitan regions, for example a disrupted environment, transport problems, pollution, crime, etc. (National Strategic Reference Framework...).

The remaining NUTS 2 regions in Czechia can be divided into four groups:

- Regions with strong economic growth that are catching up with the EU average (about 70\%): South-West (Jihozápad) and Central Bohemia (Střední Čechy),

- Regions with low-moderate economic growth: South-East (Jihovýchod) and North-East (Severovýchod),

- Regions lagging behind because of very slow growth: Central Moravia (Střední Morava),

- Declining regions: Moravia-Silesia (Moravskoslezsko) and North-West (Severozápad), i.e. regions with coal basins having structural problems.

The current unemployment rate is about 8\% in total (September 2012), but in some districts it even reaches $20 \%$ - in coal basin regions, i.e. Moravia-Silesia region and Ústecký region. The minimum value is in the Prague metropolitan area (up to 3\% registered). In other NUTS 3 regions, the unemployment rate decreases roughly from west to east. In general, rural regions display worse results than metropolitan ones (Ministry of Labour and Social Affairs).

\section{Transport aspects}

Due to its position in Central Europe, Czechia is well-advantaged to make the most of its good transport accessibility. The country is indeed covered with a dense network of railways and roads, but they do not always meet the standards demanded by modern transport. Railway network density is historically higher in the northern part of the Czech territory. The main corridors are the axes Dresden - Prague - Brno - Vienna and Katowice - Ostrava - Břeclav - Vienna. Main motorways are constructed radially from Prague towards other regional capitals. The main motorway connects Prague, Brno and Ostrava (D1). 


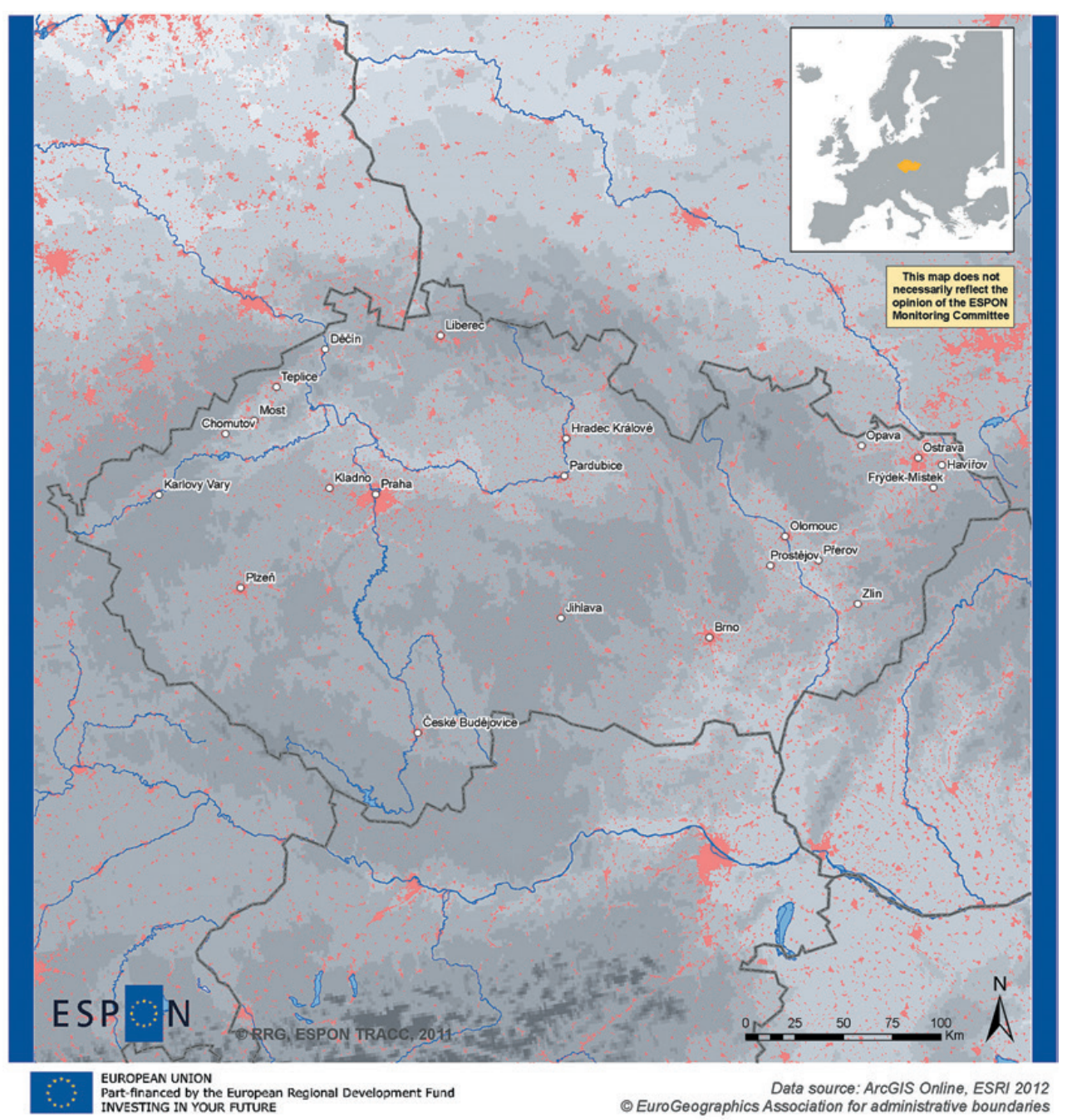

\section{Czech Republic Case Study Physical map}

- Main city

\section{Settlement area}

Figure 1. Czech Republic case study region.

Since 1990, the shares of the various modes of transport have changed substantially, in relation with a general transition of the society and the country's accession to the EU (2004). The greatest decline in performance and the volume carried was noted by railway, public road transport (passenger), and water transport (which has always been minor). On the other hand, transport by heavy trucks of over 12.5 tonnes has increased substantially, as well as individual road passenger and air transport. Performance of all the transport modes with a negative impact on the environment has 
increased. The Prague international airport ranks among major Central European ones. Its capacity has increased from 1.8 million passengers in 1989 to 11.6 million in 2010. Prague airport handles nearly $94 \%$ of air passengers in Czechia.

\section{Accessibility patterns}

Accessibility indicators used in the study presented here follow the common methodology of the ESPON TRACC project (Biosca et al. 2013). The model used in all ESPON analysis in this regional case study has been developed at the Faculty of Science, Charles University in Prague (PrF UK), Department of Social Geography and Regional Development and Department of Applied Geoinformatics and Cartography. The road accessibility model was constructed using the CEDA shape file of vectorised transport network (2006). The status of the network has been updated continuously and, after the correction check, it was transferred into Network Dataset in ArcMap software. According to the study by T. Hudeček (2008), individual categories of roads were assigned different average speeds. Apart from the road category, also inclination, physical environment (built-up areas/undeveloped land) and official traffic rules were taken into account when determining the speed level. Afterwards, the model was tested to maximally approximate the results to the reality. The specific speeds for individual sections are the following:

- Motorways (D) $-115 \mathrm{~km} / \mathrm{h}$,

- Expressways (R) - $105 \mathrm{~km} / \mathrm{h}$,

- Motorways and Expressways in built-up areas $(\mathrm{D}+\mathrm{R})-76 \mathrm{~km} / \mathrm{h}$,

- First-class roads $-67 \mathrm{~km} / \mathrm{h}$,

- Second-class roads $-48 \mathrm{~km} / \mathrm{h}$,

- First-class roads in built-up areas $-45 \mathrm{~km} / \mathrm{h}$,

- Second-class roads in built-up areas $-35 \mathrm{~km} / \mathrm{h}$,

- Third-class roads $-32 \mathrm{~km} / \mathrm{h}$,

- Local roads in built-up areas $-25 \mathrm{~km} / \mathrm{h}$.

The public transport accessibility model was created by merging the road accessibility model with the railway network shapefile from Arc ČR 500 and ArcData official databases. Both segments were connected with the help of artificial connectors of railway stations and the closest point on the road network. These connectors were assigned walking speed of $5 \mathrm{~km} / \mathrm{h}$. The speed of buses on roads was derived from timetables. According to 20 selected local bus connections and 20 long-distance ones, average speed of $35 \mathrm{~km} /$ hour was determined. In the case of rail speeds, the approach of the RRG partner was used. According to timetables from recent years (2008-2010), individual segments of the network were assigned different speeds. Speeds for types/categories of railway sections were specified as follows (average maximum speeds in $\mathrm{km} / \mathrm{h}$ ):

- Main line, double track, electrified $-77 \mathrm{~km} / \mathrm{h}$,

- Main line, double track $-52 \mathrm{~km} / \mathrm{h}$,

- Main line, single track, electrified $-57 \mathrm{~km} / \mathrm{h}$,

- Main line, single track - $52 \mathrm{~km} / \mathrm{h}$,

- Secondary line, single track, electrified - $32 \mathrm{~km} / \mathrm{h}$,

- Secondary line, single track $-37 \mathrm{~km} / \mathrm{h}$. 


\section{Daily accessibility of jobs by car}

During the transformation period, after the political changes in 1989, job opportunities have been concentrated in hierarchically more important settlement centres. The trend was supported by the decrease in, often artificially maintained, employment in agriculture in areas with unfavourable natural conditions and in small rural industrial plants established or promoted within the so-called socialist industrialization. Job opportunities in the smallest municipalities have been decreasing on a long-term basis. The map below (Figure 2) shows the number of job opportunities accessible within a 60 minutes' drive by a passenger car. It is necessary to point out that the data on job opportunities refer to 2001 (the last census with available data). In the last 10 years, job opportunities have been concentrated in larger towns (with a population of over 10,000) even more (Marada et al., 2010). The results imply the most significant potential for the residents of municipalities in the broad hinterland of Prague as there is more than one million of theoretically available job opportunities (situated in Prague and its suburbs) at an hour's distance. Furthermore, radial expressways can be observed in the agglomeration of Prague, which results in higher accessibility of job opportunities from more distant municipalities. Similar conditions for municipalities with good accessibility can be noticed around all remaining regional capitals (despite the absolute number of job opportunities being significantly lower). The results also identify municipalities with a minimum number of available job opportunities (border areas, inner peripheries at regional borders), which have been stagnating in terms of economic development in the long term.

The population relying on public transport is more strongly dependent on job opportunities in regional capitals or near their home, but accessibility of larger centres is insufficient. The regional focus of public mass transport and its slow speed (mainly buses) does not make long-distance daily commuting possible by virtue of its nature. An increased influence of the settlement structure can be observed for the same reason - compared to Bohemia, Moravia has the advantage of the in-line arrangement of the regional capitals and the existence of larger villages. In particular, the southern and western parts of Bohemia suffer from fragmentation of settlements and the absence of larger town centres.

Expressing accessibility as a cumulated opportunity provides a new view of some peripheral areas. For example, despite being distant from the regional capitals, the relatively lagging area between Prague, Hradec Králové and Liberec can benefit from the offer of job opportunities in all the three centres. A similar effect can be observed in central Vysočina (Pardubice, Jihlava, Brno, Prague) or on the boundary between the Central Bohemian and South Bohemian regions. The essential importance of the express transport infrastructure (including railways) is also apparent, as evidenced by relatively isolated South or East Bohemia as well as the frontier areas bordering Bavaria and Poland.

\section{Regional accessibility potential by car}

In aggregate, the results of the potential accessibility show the main concentration areas and their locations in the transport networks in Czechia. The map clearly illustrates the relative separation of the two historically autonomous settlement systems of Czechia (Moravia vs. Bohemia). The Moravian system is dominated by the Brno - Olomouc/Zlín - Ostrava axis, while Bohemia is dominated by Prague situated in the centre of the radial system of roads and railways. The following have been highlighted among isolated agglomerations: South Bohemian centre of České Budějovice, relatively weak NUTS 3 centre of Karlovy Vary and Jihlava. The former two regional capitals have not been connected to the complete motorway network yet. Areas with the worst potential accessibility include, 
first of all, the sparsely populated border areas and, secondly, so-called inner peripheries. The map also shows the positive impact of unfinished motorway axes and first-class roads which substitute for absent motorways. Examples are: R4 from Prague heading to South-Western Bohemia, R35 from Olomouc to North-Western Bohemia or I/3 from Prague to the south of Bohemia. The map indicates a useful potential of the structurally affected region of South-Western Bohemia with vast residential areas that is relatively close to the Prague centre. Czechia is presented in this analysis in an isolated way, i.e. with no relations to the neighbouring states. When taking into account foreign centres, the potential accessibility of North-Western Bohemia would be even higher thanks to the presence of Dresden, and the region of Ostrava communicating with the region of Polish Katowice would also stand out.

\section{Access to regional centres by public transport}

Figure 4 shows a map of time accessibility of important residential centres in Czechia (towns with a population of more than 50,000). The results imply significant geographic differentiation of municipalities in respect of time accessibility. On the one hand, they highlight the hinterland of all agglomerations where mobility of residents is of high significance (dominated by commuting to work, school and services). Disparities in time accessibility are affected by the current condition of road infrastructure in Czechia. On the other hand, the results show the most distant and peripheral areas located primarily at the borders with Poland (Krkonoše and Jeseníky Mts.) and Bavaria (Šumava Mts.). There are also so-called inner peripheries in Czechia, which can be found around the borders of NUTS 3 regions (mainly around the Central Bohemian region and between Bohemia and Moravia). These areas are predominantly characterized by the decline in the resident population and other socio-economic indicators of a below-average level. The transport-related exclusion of the residents is an important factor here. This is for example the interface of the Central Bohemian and South Bohemian regions or the border between the Pardubice and Vysočina regions.

The concentric shape of accessibility zones results from the lower speed of public transport. The results also show much more peripheral communities where travelling by public transport takes more than 80 minutes. For most of these communities it is typical that there is an above-average number of vehicles in households as it partially compensates for insufficient public transport offer. Although Czechia has a relatively good and stabilized offer of public transport (compared to other Western European states), competition from private vehicles is very important as more and more people prefer to commute by car instead of using public transport (Marada, Kveton 2010). Nevertheless, integrated transportation systems have been introduced in most areas around regional metropolises in Czechia and the position of public transport in the hinterland of large regional centres is very strong. On the other hand, the transport-related exclusion of various disadvantaged groups of residents of peripheral municipalities (in terms of transport) is becoming a significant threat for the future (Kveton 2006).

\section{Access to health care facilities by car}

The health care infrastructure (hospitals) in Czechia is very evenly distributed because it still builds upon the district-based arrangement established by the totalitarian regime. The accessibility of health care for the population is still relatively balanced in each region, but the health care system is currently being restructured. The process will include liquidation of some hospitals or reorganization of the emergency system. There are 189 hospitals in Czechia (in 2010, 19 were managed by the Ministry of Health, 24 were managed by the regions, 17 hospitals were managed by communities/towns and the remaining hospitals were managed by other legal entities). The results of time accessibility of 
hospitals show that a large majority of municipalities are within a 40-minute distance. Although the accessibility of health care institutions is laid down in the law, it is very diverse in practice. The worst accessibility is from municipalities in the border areas of Czechia. Most hospitals are located in the major residential centres situated inland.

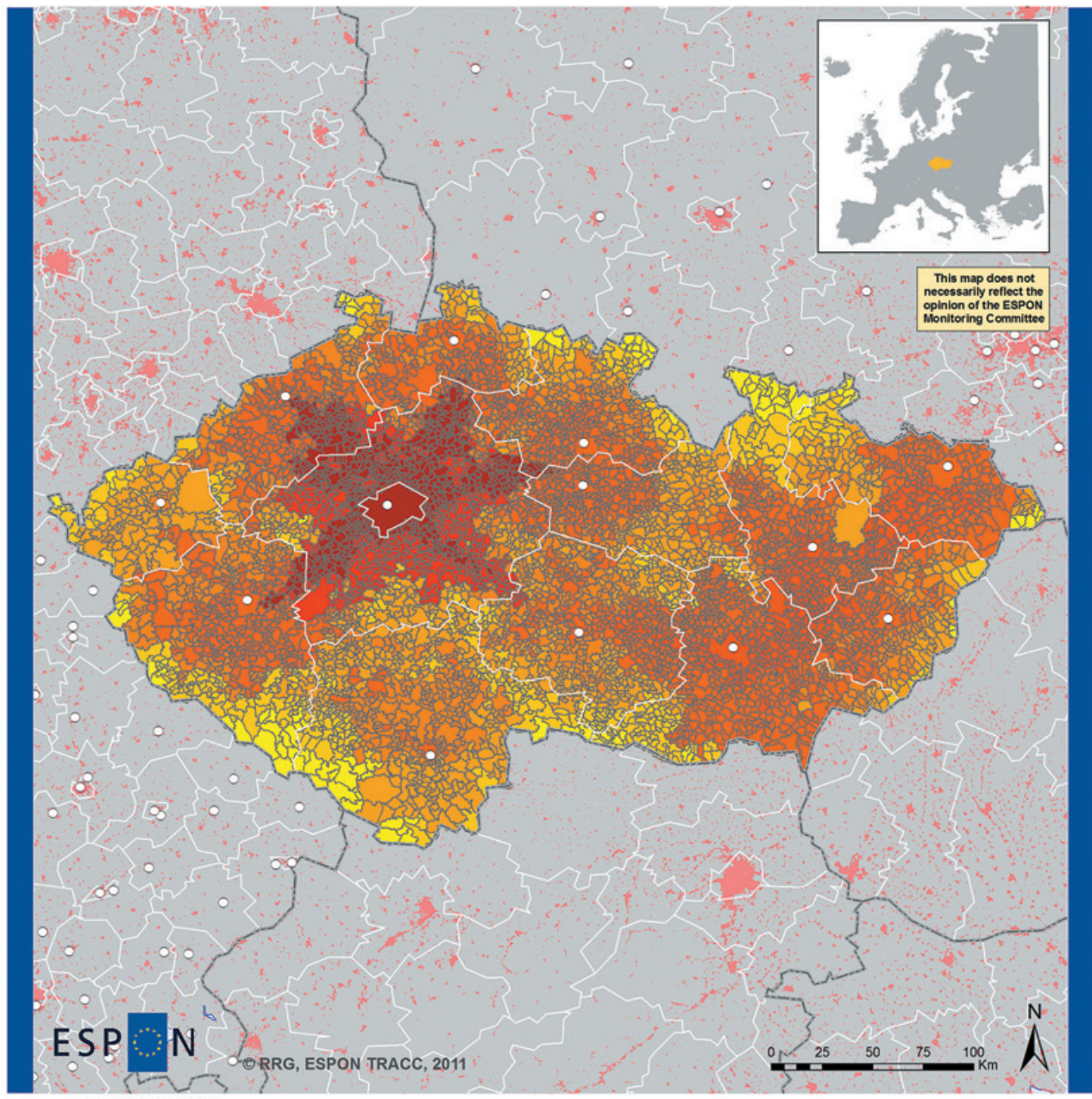

EUROPEAN UNION INVESTING IN YOUR FUTURE

Source: Population and Housing Census, 2001 PrF UK Prague - accessibility model CAR Origin of data: ESPON Databank Project, 2010/2011 (c) EuroGeographics Association for administrative boundaries

\section{Czech Republic Case Study}

Daily accessibility of jobs by car

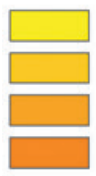

$0-50,000$

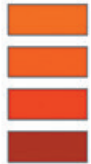

$200,001-500,000$

NUTS 3 Capitals

$50,001-100,000$

$100,001-150,000$

$500,001-750,000$

$150,001-200,000$

$750,001-1,000,000$

$1,000,000<$

Figure 2. Jobs accessible by car within 60 minutes. 


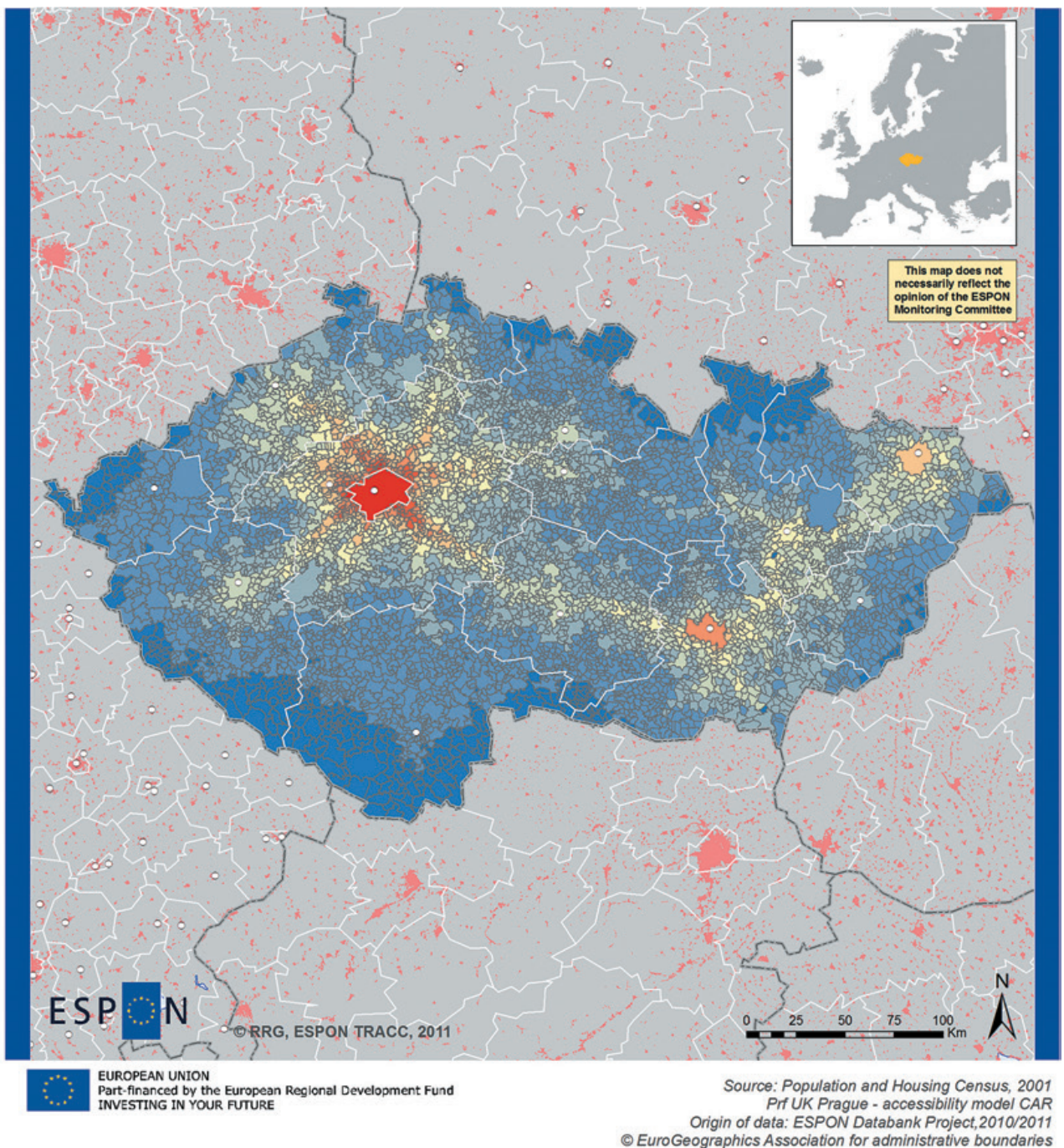

\section{Czech Republic Case Study}

Potential accessibility to population by car $[\beta=0.034657]$
$0-25$
$25,1-50$
$50,1-75$
$75,1-100$
$100,1-125$
$125,1-150$
$150,1-175$
$175,1-200$
$200<$

- NUTS 3 Capital

100 (population weighted average $)=\mathbf{5 2 4 0 3 0 , 6 7 5 5}$

Minimum: 2525076,61985

Maximum: 1631466,974

Figure 3. Potential accessibility to population by car. 


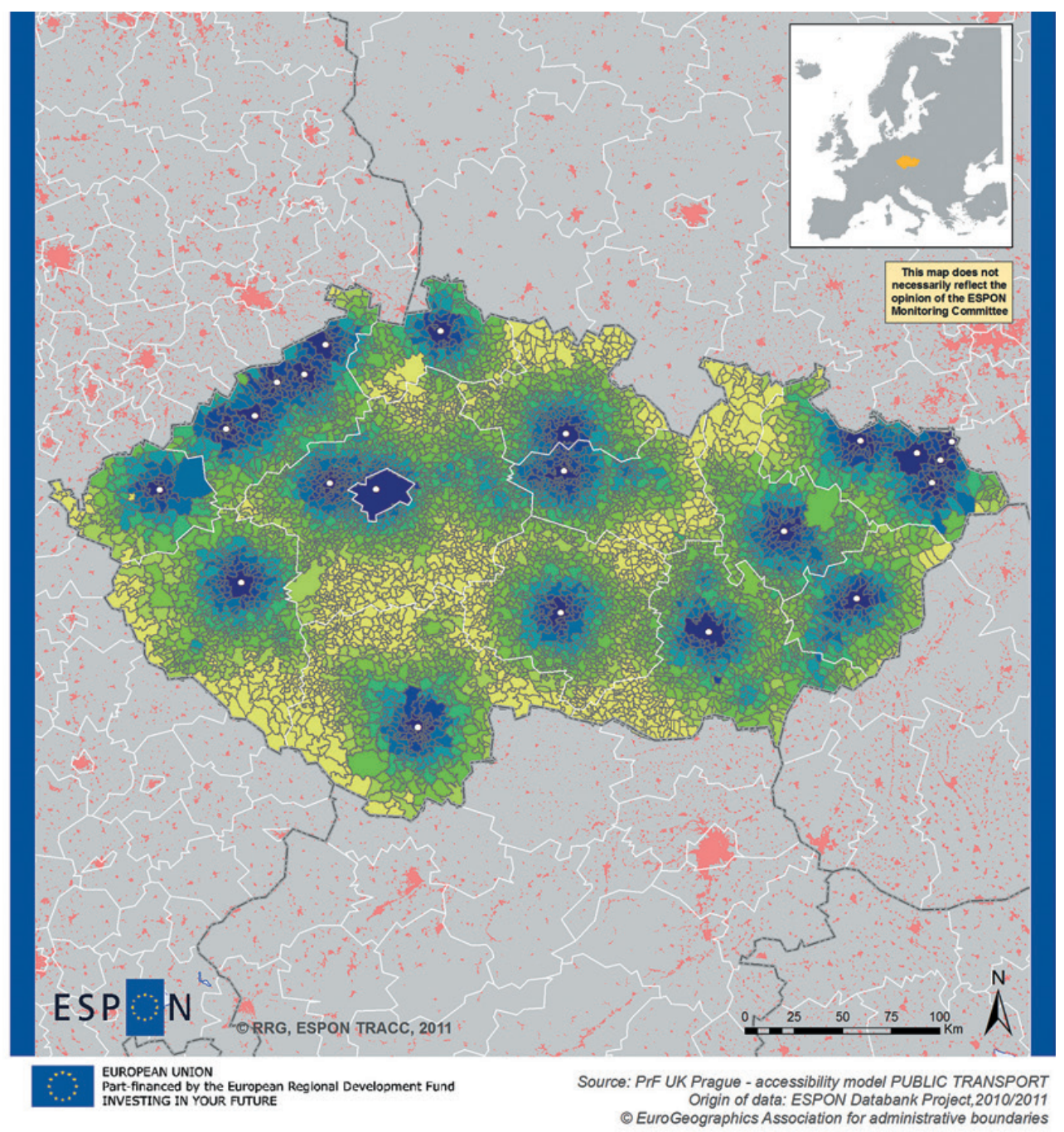

\section{Czech Republic Case Study}

Travel time to regional centre by public transport [min]

\begin{tabular}{lll}
\hline $0-10$ & $\square$ & $51-60$ \\
$11-20$ & $\square 1-70$ \\
$21-30$ & $\square$ \\
$31-40$ & & $71-80$ \\
& & \\
$30<$
\end{tabular}

$41-50 \quad$ Regional centre $(50,000>)$

Figure 4. Travel time to nearest regional centre by public transport. 


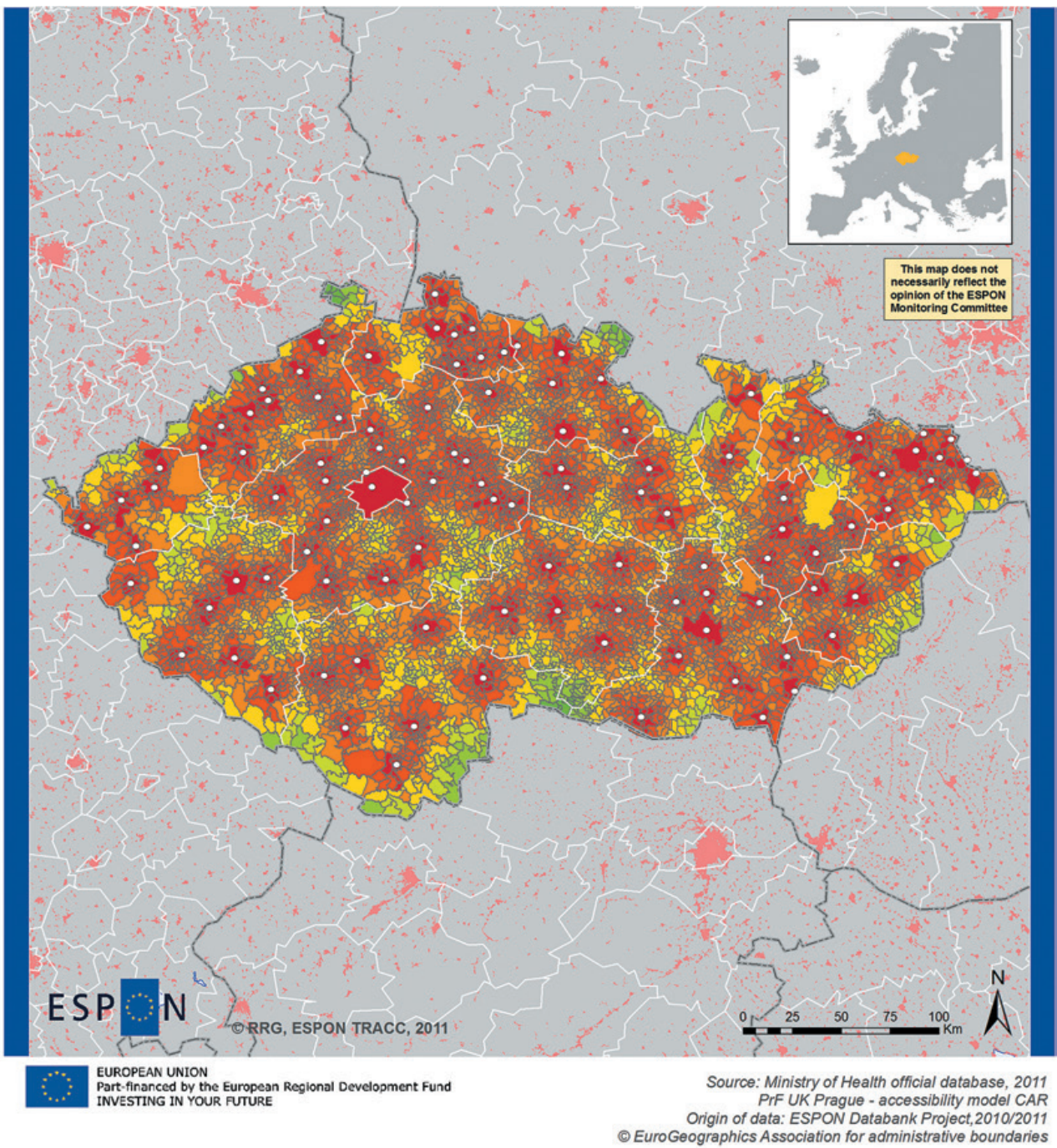

\section{Czech Republic Case Study} Travel time to closest hospital by car [min]

\begin{tabular}{|lll|}
\hline $0-10$ & $\square$ & $41-50$ \\
& & \\
$11-20$ & $\square 1-60$ \\
& & \\
$21-30$ & & $60<$ \\
\hline $31-40$ & $\circ \quad$ & Hospital \\
\hline
\end{tabular}

Figure 5. Travel time to nearest hospital by car. 


\section{The impact of the future TEN-T road network developments}

The European dimension is very important for the development of the transport infrastructure in Czechia. The currently pending proposal for a Regulation on the Union's guidelines for the development of TEN-T will be a very crucial aspect for determining long-term strategy of transport development. High quality transport infrastructure as an essential condition for traffic is a one of the key aspects for solving transport issues. Transport accessibility is ensured for all self-administrative regions, but not with sufficient quality. This is one of the reasons behind the disequilibrium position of the regions, as the quality of transport services is one aspect of the competitiveness of the regions (EC 2003). If the draft Regulation on the development of TEN-T is adopted in its current form, Czechia is bound to complete the transport infrastructure of the main TEN-T and multimodal corridors in rail, road, water and air transport by its commitment for 2030. By 2050, the Czech Republic committed to complete the remainder of the TEN-T (the global network). Despite completion of the motorway network, the introduction of high-speed rail should be the most substantial driving force. The rail track between Dresden and Vienna through Prague, track from Prague via Wrocław and via Katowice region are proposed. Currently only high-speed connection between Prague and North-West Bohemia (via Dresden) is discussed (Ministry of Transportation).

Figure 6 below shows potential accessibility to the population by car transport with TEN-T projects once they are completed. Compared with the current situation, these results clearly illustrate the positive effects of transport projects included in the TEN-T programme (EC 1999, 2002a, 2002b). Impacts of new TEN-T infrastructure will have a stimulating effect on potential accessibility and population mobility. TEN-T infrastructure projects will significantly enhance potential accessibility in hinterland of the most important agglomerations and will support transport connection among key settlement centres in Czechia. In the case of public transport impacts, which were standardised to car transport, it seems it would strengthen transport relations of Prague with North and East Bohemia regions and cities. At the same time, the finishing of selected parts of TEN-T projects would positively influence the transport situation in Moravia-Silesia regions (especially in the cities of Brno, Ostrava and Olomouc). A relative increase in potential accessibility to the population by car with TEN-T projects shows very clearly that all regions will be affected by new infrastructure projects. In the case of car accessibility potential, the contribution for the most of municipalities in Czechia is evident.

The analyses presented herein were performed at the national level, but the importance of TEN-T corridors for international interconnection is also apparent. This is particularly the case for axes Prague - Dresden, Prague - Nurnberg/Munich, Prague - Wroclaw or Brno - Vienna. 


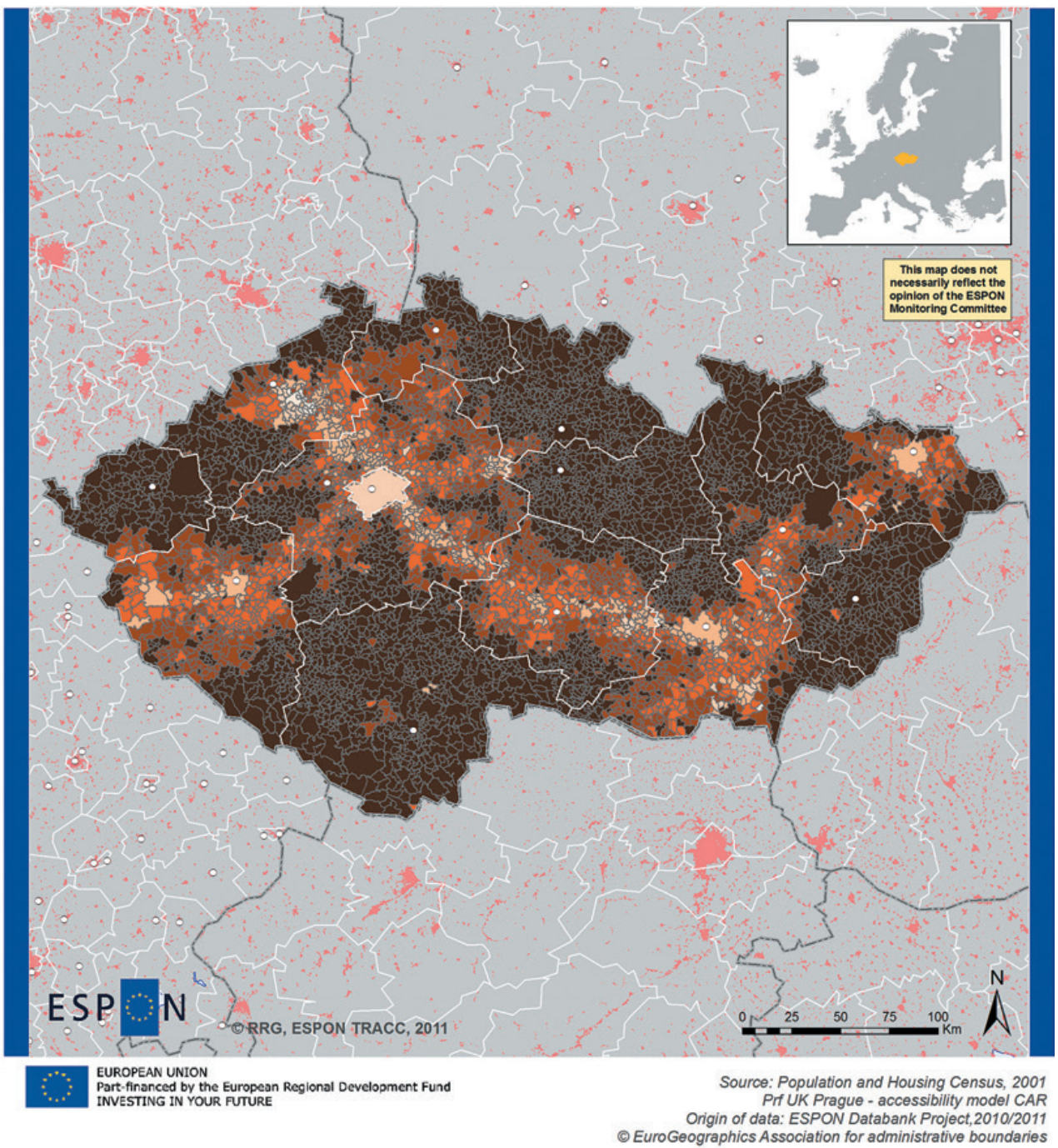

\section{Czech Republic Case Study}

\section{Potential accessibility, relative change - car}

$-22,7-5,0$

- NUTS 3 Capital

$5,1-20,0$

$20,1-35,0$

$35,1-50,0$

$50,1-65,0$

$65,1-285,9$

Figure 6. Relative increase in potential accessibility to population by car with TEN-T projects. 


\section{Conclusions}

The case study identified regional transport patterns in Czechia. The accessibility model used in all ESPON analyses in this regional case study was developed at the Faculty of Science, Charles University in Prague (PrF UK), Department of Social Geography and Regional Development and the Department of Applied Geoinformatics and Cartography. The model used for the evaluation of transport accessibility presents the major results for access to regional centres, daily accessibility of jobs, potential regional accessibility, access to health care facilities and accessibility of upper secondary schools.

Czechia has a relatively high density of road network, while the basic network of motorways and expressways has not been completed and does not match the actual needs. Some regional centres still do not have a good connection with the network of motorways and expressways (České Budějovice, Karlovy Vary, Zlín). Similarly, it is necessary to continue building bypasses around settlements and to relieve the city centres from the traffic load. Main railway corridors have been renovated recently for max. speed of $160 \mathrm{~km} / \mathrm{h}$. There is still no high speed rail.

From the key results of the Czechia case study it is possible to derive the following conclusions:

- The results of major regional centres in terms of their accessibility imply a significant geographic differentiation of municipalities in respect of time accessibility of key settlement centres in Czechia. On the one hand, they highlight the hinterland, while on the other hand the results highlight the most distant and peripheral areas located primarily at the borders with Poland and Bavaria. There are also so-called inner peripheries in the Czech Republic, which can be found around the borders of the NUTS 3 regions. Disparities in time accessibility are primarily the result of the current condition of the road (motorway) infrastructure, and secondarily of the railway infrastructure in Czechia. The main difference between car and public transport accessibility is the size of the hinterland with time accessibility of up to 30 minutes and its concentric shape resulting from the lower speed of public transport.

- The results for job accessibility display the most significant potential for the residents of municipalities in the broad hinterland of larger agglomerations (Prague has exceptional value from this point of view). Radial expressways result in higher accessibility of job opportunities from more distant communities by car. The results also identify communities with the minimum number of available job opportunities (border areas, inner peripheries at regional borders). Expressing accessibility as a cumulated opportunity provides a new view of some peripheral areas. Some municipalities located in between several regional capitals can benefit from the offer of job opportunities in all surrounding centres. The population relying on public transport is more strongly dependent on job opportunities in regional capitals or near their home. The importance of suburban railroads is evident.

- Contrary to time and cumulated accessibility, potential accessibility takes into account the weight of potential destinations of origin. The results for the potential accessibility indicator considering the population size of municipalities (LAU2) shows the main concentration areas and their locations in the transport networks in Czechia. There is relative separation of the two historically independent settlement systems of Czechia (Moravia vs. Bohemia). The key role of motorways in terms of accessibility is evident (NUTS 3 centres not connected with the 
motorway system are relatively isolated). Areas with the lowest potential accessibility include, first of all, the sparsely populated border area and, secondly, so-called inner peripheries.

- Modelling the impact of future TEN-T corridors proved the key importance of improved domestic interconnections of Bohemia and Moravia (east-west directions, R35 alternative corridor to D1 motorway) as well as of European links, mainly with Dresden/Berlin, Nurnberg, Munich, Vienna, Krakow and Wrocław.

A sharp increase in the volume of road transport, both freight and passenger, is typical for Czechia in the last 20 years. In the period until 2020, we can expect continued growth in individual passenger transport. In the road freight transport, there will possibly be an increase in performance by further 30 to $40 \%$ by 2020 . The actual course of the performance increase will be affected by the overall economic situation, the amount and extent of tolling (including the internalisation of external costs), not only in Czechia but also in the neighbouring countries, as well as fuel prices.

\section{Annex}

\section{Accessibility model sources}

\section{Database:}

- Settlements (PrF UK GIS Database; derived from Arc CR),

- Road network dataset (PrF UK GIS Database, based on Arc CR),

- Public transport network dataset (PrF UK GIS Database, based on Arc CR),

- Public transport timetables: www.idos.cz [25 September 2013],

- 2001 Population and Housing Census: www.czso.cz.

Network database:

ArcČR500 (1:500,000), CEDA 150 (1:150,000), Road and Motorway Directorate of the Czech Republic, Czech Statistical Office - Population and Housing Census 2001.

\section{References}

Biosca O., Spiekermann K., Stępniak M., 2013. Transport accessibility at regional scale, EUROPA XXI, vol. 24, pp. 5-17.

European Commission, 1999. 14 TEN Priority Projects. http://europa.eu.int/en/comm/dg07/ tentpp9807/indexhtm [25 September 2013].

European Commission, 2002a. Revision of the Trans-European Transport Networks "TEN-T". Community Guidelines. Brussels: European Commission, http://europa.eu.int/comm/transport/ themes/network/english/ten-t-en.html [25 September 2013].

European Commission, 2002b. Trans-European Transport Network. TEN-T priority projects. Luxembourg: Office for Official Publications of the European Communities.

European Commission, 2003. A European Initiative for Growth. Investing Networks and Knowledge for Growth and Jobs. Final Report to the European Council.COM(2003)690 final/2. Brussels: Commission of the European Communities. 
European Regional Prospects, CAMBRIDGE ECONOMETRICS, 2010 Cambridge.

Hudeček T., 2008. Model časové dostupnosti individuální automobilové dopravy. Geografie, 113, Vol. 3, pp. 140-153.

Hůrský J., 1978. Regionalizace České socialistické republiky na základě převládajícího spádu osobní dopravy. Studia geographica, vol. 59, Brno: Geografický ústav ČSAV.

Květoň V., 2006. Hodnocení dopravních možností obyvatel: analýza okresů Česka a mikroregionální pohled. Diplomová práce, Praha: Katedra sociální geografie a regionálního rozvoje PřF UK.

Marada M., Hudeček T., 2006. Accessibility of Peripheral Regions: A Case of Czechia. Europa XXI 15, Warszava, pp. 43-51.

Marada M., Květoň V., Vondrackova, P., 2010. Doprava a geografická organizacespolečnosti $v$ Česku. EdiceGeographica, ČGS, Praha, 161 pp.

Marada M., Květoň V., 2010. Diferenciace nabidky dopravních přiležitostí v českýchobcích a sociogeografických mikroregionech. Geografie - Sborník ČGS, 110, č. 1, pp. 21-43.

MMR ČR, 2006. Strategie regionálního rozvoje České republiky. Praha: Ministerstvo pro místnírozvoj ČR. 